\title{
Variation of Wood Density and Anatomical Characters from Altitude Differences: Case Study of Selected Fabaceae Trees in West Sumatra Secondary Forest, Indonesia
}

\section{Linda Syofyan¹, Tesri Maideliza², Syamsuardi², and Mansyurdin²}

${ }^{1}$ Doctoral Program of Biology, Faculty of Mathematics and Natural Sciences, Andalas University, Padang, 25163, Indonesia

${ }^{2}$ Department of Biology, Faculty of Mathematics and Natural Sciences, Andalas University, Padang, 25163, Indonesia

\section{Abstract}

There are three tree species of Fabaceae used for furniture in the secondary forest of coastal to mountain areas in West Sumatra, Indonesia. Their wood samples were collected from secondary forests of altitude ranges. Wood density was calculated as

Corresponding Author:

Mansyurdin

mansyurdin@sci.unand.ac.id

Received: 19 February 2019

Accepted: 5 March 2019

Published: 16 April 2019

Publishing services provided by

Knowledge E

(c) Linda Syofyan et al. This article is distributed under the terms of the Creative Commons Attribution License, which permits unrestricted use and redistribution provided that the original author and source are credited.

Selection and Peer-review under the responsibility of the ICBSA Conference Committee. dry weight divided by green volume. The anatomical characters are measured on transverse, radial and tangential sections. The results showed that Senna sumatrana showed moderately heavy of wood density at $\leq 600 \mathrm{~m}$ asl, Gliricidia sepium at $>600 \mathrm{~m}$ asl, and Pterocarpus indicus at altitude 300 to $900 \mathrm{~m}$ asl. There are negative correlation between wood density and altitude on $S$. sumatrana $(r=-0.967)$, negative correlation on $G$. sepium ( $r=+0.918$ ) and $P$. indicus $(r=+0.898)$. A ray height shows the positive correlation with the altitude for S. sumatrana $(r=+0.957)$, G. sepium $(r=+0.898)$, and $P$. indicus $(r=+0.898)$, while other anatomical characters may exhibit positive or negative correlation. Based on analysis of multiple correlations that the wood density variables of $S$. sumatrana, $G$. sepium and $P$. indicus is determined by anatomical character variables with $r-0.998,+0.987$ and +0.993 respectively. This finding suggests that the relationship between wood density and anatomical characters of these three species can be described successfully using multiple regression equation models. The relative contribution of determinant for wood density value in S. sumatrana was determined by fiber, vessel and rays components, but $G$. sepium was determined by fiber and rays components, and $P$. indicus was determined by fiber only.

Keywords: wood density, anatomical characters, Fabaceae trees, altitude

\section{Introduction}

Biodiversity of Indonesian lowland forests has a serious threat due to greatest of damage, fragmentation and degradation of habitat, and over exploitation of resources 
2000 to 2009 [2, 3]. In anticipating deforestation, the Indonesian government has involved the role of local communities to protect forests through a community timber plantation program called The Community Timber Plantation. Through the program, over 5 million hectares of new plantation has been established in 2016 [4]. Due to over-exploitation, high value timber is rarely found in natural forests, so the Community Timber Plantation tends to grow fast growing trees.

In generally, fast-growing tree species include the Fabaceae family. Syofyan et al. [5] have found 12 tree species of Fabaceae in the secondary forest of West Sumatra. Some tree species include fruit-producing trees for consumption, shade trees, and timber producers for furniture, house poles, and firewood for residents. Senna sumatrana Roxb., Pterocarpus indicus Willd. and Gliricidia sepium (Jacq.) Stud. are three tree species commonly used by residents for furniture and have the potential to be developed in Community Timber Plantation. S. sumatrana is one of the wood-producing trees that is less well known and used for furniture [6]. G. sepium has the potential to be a major lesser used species of timber and could substitute some economic species in Nigeria's timber market [7]. P. indicus has been developed for industrial processing in Papua New Guinea [8], introduced and cultivated in China because of their growth performances and ecological adaptabilities [9].

Wood quality is determined by wood density related to the physical properties of wood, and it can be determined by wood density. Wood density is affected by the growth site [10-13]. Wood density variation due to place can be caused by factors of edaphic categories [14], shade-tolerance [15], planting density [16], elevation [17, 18], and altitude gradient [19], adverse weather conditions [20], High or low wood density due to allocating biomass or $\mathrm{C}$ to stem development $[21,22]$.

Wood density is closely related to mechanical properties over a wide range of raw material types [23], longitudinal, radial, tangential, and volumetric shrinkage [24], modulus of elasticity and modulus of rupture [25]. The plant response to the altitudinal gradient is more focused on anatomical adaptations than morphological variation, it also species dependent [26]. Considering the spread of tree species of the Fabaceae tree found in the coastal areas to the mountains of West Sumatra, it has been conducted on the relationship between wood density and anatomical characters based on altitude gradients.

\section{Materials and Methods}




\subsection{Collection of wood samples}

Wood samples were collected from various secondary forest sites (Padang, Pesisir Selatan District, Pasaman District, and Solok District) of West Sumatra province, Indonesia. The location of secondary forest is grouped into four ranges of gradient altitude, i.e. 0-300 m asl, 300-600 m asl, 600-900 m asl and 900-1,200 m asl [26]. Wood samples ware taken at breast height (about $120 \mathrm{~cm}$ above ground from a minimal tree with a diameter of $20 \mathrm{~cm}$ ). Four pieces of heartwood (20 cm from bark) sections $10 \mathrm{~cm}^{3}$ were collected from four opposite sides of the stem with replications of three individuals per species.

\subsection{Measurement of wood density}

For wood density measurement, four wood pieces are provided with three individuals per species. The wood density was obtained by measuring a wet volume of the wood piece and its oven-dry weight. To measure the volume of wood pieces, a water-displacement method is used [27]. A volume of water equal to the volume of wood (at field moisture content) was weighed. Displacement was accomplished by immersing wood piece in a beaker of water. Wood samples were oven-dried at $85^{\circ} \mathrm{C}$ to constant mass. Wood density was calculated as dry weight divided by green volume [28]. Wood density classification is grouped according to Wong [29], i.e. light $(<0.5$ $\mathrm{g} / \mathrm{cm}^{3}$ ), moderately heavy (between $0.5-0.8 \mathrm{~g} / \mathrm{cm}^{3}$ ), heavy (between $0.8-1.0 \mathrm{~g} \mathrm{~cm}^{3}$ ) and very heavy $>1.0 \mathrm{~g} / \mathrm{cm}^{3}$ ).

\subsection{Measurement of anatomical characters}

Wood samples with size $2 \times 2 \times 2 \mathrm{~cm}$ boiled in glycerin $30 \%$ until soft. The wood samples were sectioned by using a sliding microtome with a thickness of $15-20 \mu \mathrm{m}$ in the transverse, radial and tangential fields. The sections were dehydrated in a series of alcohol solutions of $10 \%, 20 \%, 30 \%$ and $50 \%$ for 15 minutes respectively, and stained with $2 \%$ safranin solution in alcohol $50 \%$ for 3 hours, and excess color washed in $70 \%$ alcohol for 10 minutes. The section is further dehydrated in alcohol 90\% and absolute, and is cleaned in xylol. The section was mounted on the surface of the object glass using the New Entelan [30]. The permanent slides were observed anatomical characters under the light microscope which included a vessel diameter, height and width ray. 
For observing the characteristics of fiber, the samples were cut into small pieces (toothpick size). Small pieces macerated in fluid of aqueous nitric acid and aqueous chromic acid $(1: 1 ; \mathrm{v} / \mathrm{v})$. Staining is done in $1 \%$ solution of Safranin in absolute alcohol [31]. From elements of macerated wood, fiber length, fiber diameter and wall thickness were measured using a micrometer.

\subsection{Analisis data}

Simple correlation and coefficient of determinant were computed between wood density and altitude, and between anatomical characters and altitude. Multiple regressions between wood density and anatomical characters so as to construct a prediction model for wood density, coefficient of determination $R^{2}$ was estimated to evaluate the relative contribution of anatomical character attributes (SPSS 25). Treatment means were compared using least significant different test at level 0.05 .

\section{Results and Discussion}

\subsection{Relationship between wood density and altitude}

Wood density of S. sumatrana shows moderately heavy $(0.54 \pm 0.06$ up to $0.61 \pm 0.01)$ at $\leq 600 \mathrm{~m}$ but light $(0.43 \pm 0.01$ up to $0.45 \pm 0.03)$ at $>600 \mathrm{~m}$ asl. On the contrary, the wood density of $G$. sepium shows moderately heavy $(0.50 \pm 0.03$ up to $0.51 \pm 0.01)$ at $>600 \mathrm{~m}$ but the light is at $\leq 600 \mathrm{~m}$ asl, whereas $P$. indicus shows moderately heavy $(0.55$ \pm 0.01 up to $0.55 \pm 0.01$ ) between $>300 \leq 900 \mathrm{~m}$ asl (Table 1). Table 2 and Fig. 1 shows that there is a significant negative correlation between wood density and altitude for $S$. sumatrana $(r=-0.967)$, but positive correlation on $G$. sepium $(+0.918)$ and $P$. indicus $(r=$ $+0.898)$.

This results showed that the value of wood density based on the altitude depending on the tree species of Fabaceae. Chave et al. [28] reported that the value of wood density shows significant decreases with increasing altitude and significant differences among low-altitude geographical regions. However, spruce (Picea mariana) has higher wood density in the sites forest located at lower altitudes [32], Scots pine is higher in intermediate altitude (700 m asl) compared to low altitude ( $250 \mathrm{~m}$ asl) and in high altitude (1200 m asl) [26]. Fagus orientalis growing in the altitude 400-600 m asl had 
TABLE 1: Wood density variation of timber species of Fabaceae at different altitudes.

\begin{tabular}{|c|c|c|c|c|c|}
\hline \multirow[t]{2}{*}{ Species } & \multirow{2}{*}{$\begin{array}{l}\text { Wood density } \\
\text { and } \\
\text { classification }\end{array}$} & \multicolumn{4}{|c|}{ Altitudes ranges } \\
\hline & & $\begin{array}{c}>0 \text { up to } \leq 300 \\
\mathrm{~m} \text { asl }\end{array}$ & $\begin{array}{l}>300 \text { up to } \\
\leq 600 \mathrm{~m} \text { asl }\end{array}$ & $\begin{array}{l}>600 \text { up to } \\
\leq 900 \mathrm{~m} \text { asl }\end{array}$ & $\begin{array}{l}>900 \text { up to } \\
\leq 1200 \mathrm{~m} \text { asl }\end{array}$ \\
\hline \multirow{2}{*}{$\begin{array}{l}\text { S. } \\
\text { sumatrana }\end{array}$} & WD $\left(\mathrm{g} \cdot \mathrm{cm}^{-3}\right)$ & $0.61 \pm 0.01$ & $0.54 \pm 0.06$ & $0.45 \pm 0.03$ & $0.43 \pm 0.01$ \\
\hline & Classification & $\begin{array}{c}\text { Moderately } \\
\text { heavy }\end{array}$ & $\begin{array}{c}\text { Moderately } \\
\text { heavy }\end{array}$ & Light & Light \\
\hline \multirow[t]{2}{*}{ G. sepium } & WD $\left(\mathrm{g} \cdot \mathrm{cm}^{-3}\right)$ & $0.43 \pm 0.02$ & $0.46 \pm 0.01$ & $0.50 \pm 0.03$ & $0.51 \pm 0.01$ \\
\hline & Classification & Light & Light & $\begin{array}{c}\text { Moderately } \\
\text { heavy }\end{array}$ & $\begin{array}{c}\text { Moderately } \\
\text { heavy }\end{array}$ \\
\hline \multirow[t]{2}{*}{ P. indicus } & WD $\left(\mathrm{g} . \mathrm{cm}^{-3}\right)$ & $0.40 \pm 0.02$ & $0.55 \pm 0.01$ & $0.55 \pm 0.02$ & $0.41 \pm 0.01$ \\
\hline & Classification & Light & $\begin{array}{c}\text { Moderately } \\
\text { heavy }\end{array}$ & $\begin{array}{c}\text { Moderately } \\
\text { heavy }\end{array}$ & Light \\
\hline
\end{tabular}

TABLE 2: Correlation coefficient between wood density and altitude in commercial tree of Fabaceae.

Species
S. sumatrana
G. sepium
P. indicus
* significant at 0.05 level

\begin{tabular}{|c|c|}
\hline WD \\
\hline$-0.967^{*}$ \\
\hline$+0.918^{*}$ \\
\hline$+0.898^{*}$ \\
\hline
\end{tabular}

the highest density values, and those in the altitude 0-200 m asl had the lowest density values [33].
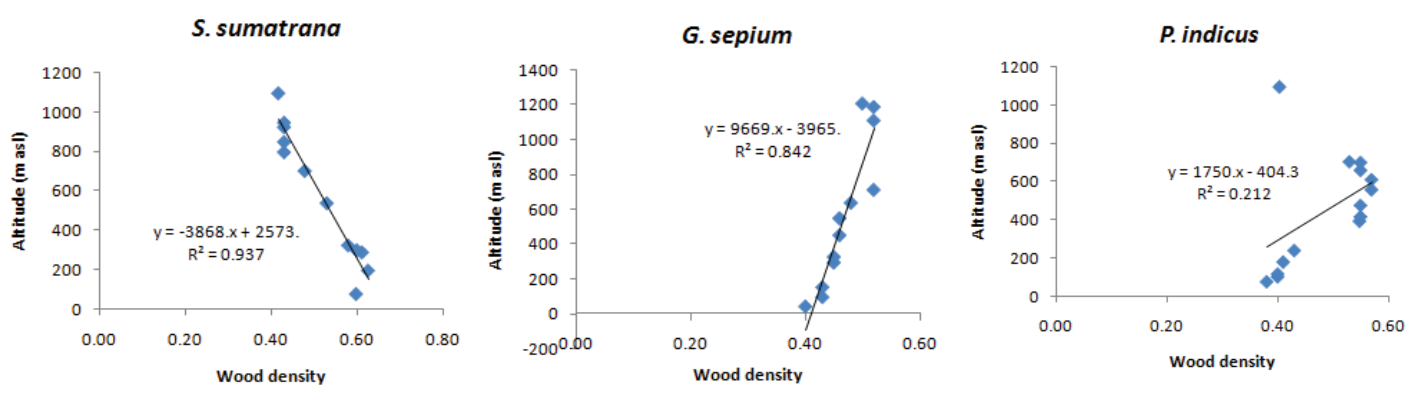

Figure 1: Regression between wood density and altitude in commercial tree of Fabaceae.

\subsection{Relationship between anatomical characters and altitude}

Fig. 2 and Table 3 shows regression and correlation between wood characters and altitude, respectively. Table 3 shows that the height ray has a positive correlation with the altitude for $S$. sumatrana, $G$. sepium and $P$. indicus denngan correlation coefficient $(r)$, i.e. $+0.957,+0.898$ and +0.898 respectively). Ray width shows positive correlation with the altitude for $G$. sepium $(r=+0.975)$ and $P$. indicus $(r=+0.839)$, but significantly 
positive correlation on S. sumatrana $(r=-0.964)$. Fiber length shows a positive correlation with the altitude for $G$. sepium $(r=+0.608)$ and $P$. indicus $(r=+0.847)$, but significantly negative correlation in S. sumatrana $(r=-0.902)$. Fiber diameter of $S$. sumatrana showed significantly positive correlation with the altitude $(r=+0.875)$ and significantly negative correlation on $G$. sepium $(r=-0.790)$.

Liang and Xin-Ying [34] reported that the height of the Lilac ray (Syringa oblate var. giradii) was gradually increased with the altitude. In Gmelina arborea, the altitude has a significant correlation with the number of cells at ray height, but the parenchyma is less stable because they are significantly affected by the altitude, latitude, longitude and precipitation [35]. The variation in ray height and ray width of Albizia procera with the site is significant that it is affected by locality and climate [36]. The ray width of Alchemilla elongate increased as elevation increased [37].

Respond of fiber quantitative character of each tree species of Fabaceae shows differences in gradient altitude (Table). Fiber wall thickness shows a positive correlation with the altitude for $G$. sepium ( $r=+0.925)$ and $P$. indicus $(r=+0.949)$, but significantly negative correlation in S. sumatrana $(r=-0.974)$. Lumen diameter of $S$. sumatrana showed a

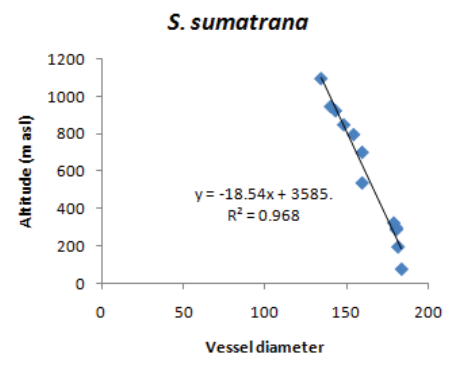

S. sumatrana
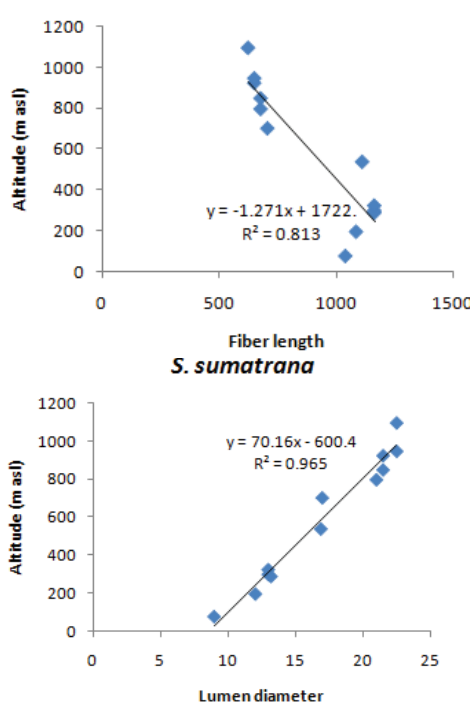

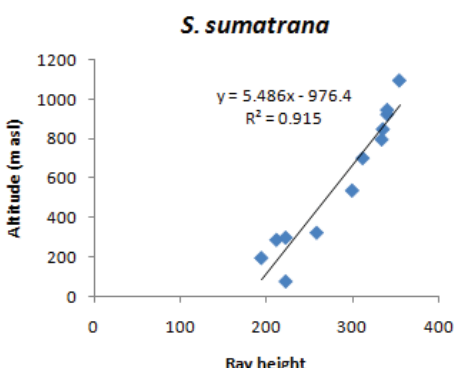

S. sumatrana

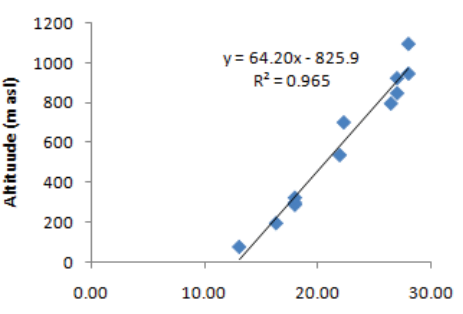

Fiber diameter

G. sepium

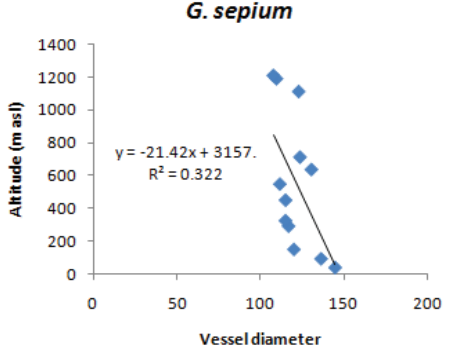

S. sumatrana

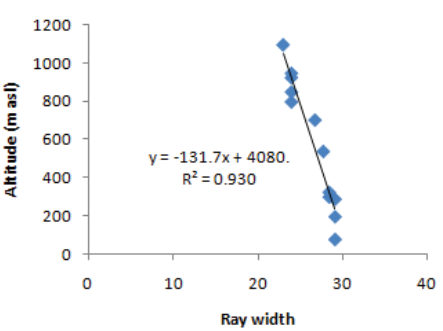

S. sumatrana

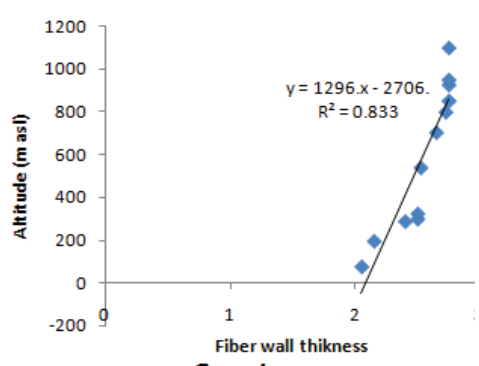

G. sepium

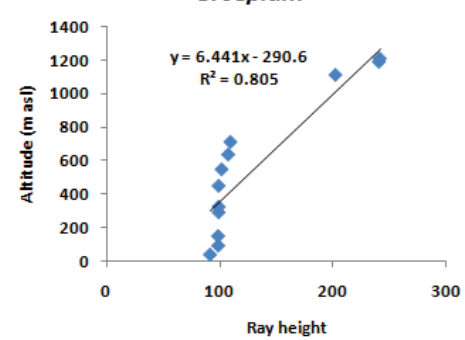



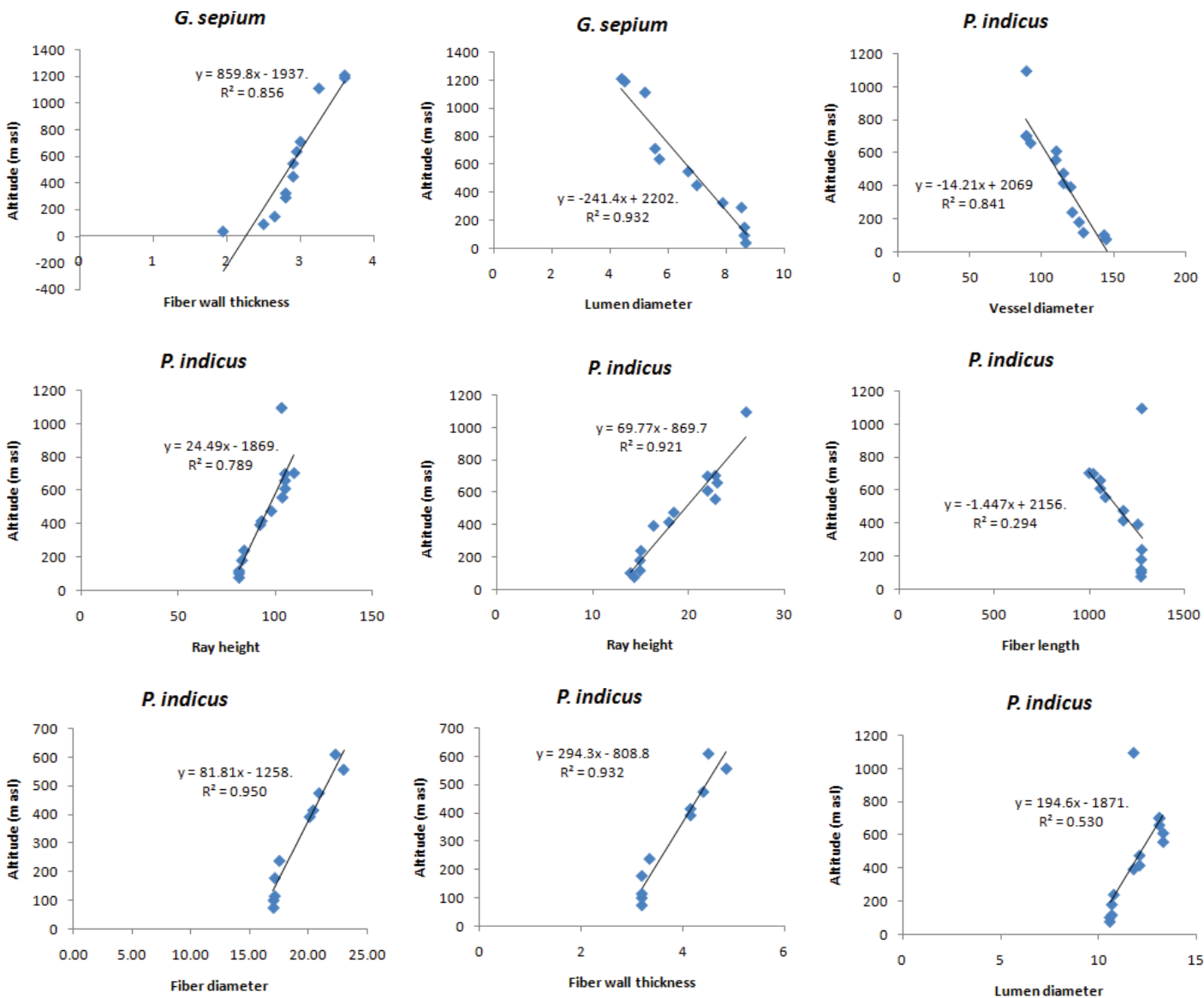

Figure 2: Regression between wood characters and altitude in selected tree of Fabaceae.

significantly positive correlation $(r=+0.953)$, but significantly negative correlation on $G$. sepium $(r=-0.966)$ and $P$. indicus $(r=-0.980)$.

TABLE 3: Correlation coefficient between anatomical charaters and altitude of selected tree species of Fabaceae.

\begin{tabular}{l|c|c|c|c|c|c|c|} 
Species & \multicolumn{7}{c|}{ Anatomical characters } \\
& $\begin{array}{c}\text { Vessel } \\
\text { diameter }\end{array}$ & $\begin{array}{c}\text { Ray } \\
\text { height }\end{array}$ & $\begin{array}{c}\text { Ray } \\
\text { width }\end{array}$ & $\begin{array}{c}\text { Fiber } \\
\text { length }\end{array}$ & $\begin{array}{c}\text { Fiber } \\
\text { diameter }\end{array}$ & $\begin{array}{l}\text { Fiber wall } \\
\text { thickness }\end{array}$ & $\begin{array}{c}\text { Lumen } \\
\text { diameter }\end{array}$ \\
\hline $\begin{array}{l}\text { S. } \\
\text { sumatrana }\end{array}$ & $-0.987^{*}$ & $+0.957^{*}$ & $-0.964^{*}$ & $-0.902^{*}$ & $+0.875^{*}$ & $-0.974^{*}$ & $+0.953^{*}$ \\
\hline G. sepium & $-0.568^{n s}$ & $+0.898^{*}$ & $+0.975^{*}$ & $+0.608^{*}$ & $-0.790^{*}$ & $+0.925^{*}$ & $-0.966^{*}$ \\
\hline $\begin{array}{l}\text { P. indicus } \\
\text { * }\end{array}$ & $-0.696^{*}$ & $+0.898^{*}$ & $+0.839^{*}$ & $+0.847^{*}$ & $-0.439^{n s}$ & $+0.949^{*}$ & $-0.980^{*}$ \\
\hline significant at 0.05 level, ns is non significant & & & & \\
\hline
\end{tabular}

In G. arborea, length and diameter of the fiber and lumen show less affected by the altitude [35]. However, the significant effect on fiber components [38], where size of fiber length and fiber diameter of $F$. orientalis wood showed an increase of 0-400 m asl and decreased from 400-100 m asl, fiber wall thickness and lumen diameters show an increase from 0-400 m asl but fiber wall thickness does not vary and lumen diameter 
fluctuates from 400-100 m asl [33]. In Q. fontica, altitude was positively correlated with tracheid fiber wall thickness of [39].

Vessel diameter showed significantly negative correlation only with the altitude in $S$. sumatrana and $P$. indicus ( $r=-0.987$ and -0.696 respectively). Strubbe (2013) reported that mean vessel area and vessel density did show significant correlation, respectively negative and positive with wood density. Decreasing growth rate with increasing altitude, the diameter of the vessels narrowed and the number of vessels in $1 \mathrm{~mm}$ increased [32]. The vessel lumen fraction is influenced by potential stem conductivity [40].

\subsection{Relationship between wood density and anatomical characters}

Based on analysis of multiple linear correlations that wood density variable of S. sumatrana, G. sepium and P. indicus were determined by anatomical character variables, correlation coefficient (r), respectively $-0.998,+0.987$ and +0.993 (Table 4). Result of multiple linear regressions showed that relative contribution of each anatomical character to predict wood density. The prediction equation was formulated as follow as equation (1), (2) and (3):

$$
\begin{gathered}
\left.\left.Y_{S s}=0.931+0.005 X_{1}-0.010 X_{2}\right)-0.002 X_{4}-0.001 X_{5}\right) \\
Y_{G s}=0.059+0.011 X_{1}+0.104 X_{2}+0.001 X_{4}-0.001 X_{5}+0.006 X_{6} \\
Y_{P i}=-1.143+0.031 X_{2}+0.098 X_{3}+0.002 X_{4}+0.002 X_{5}-0.020 X_{6}
\end{gathered}
$$

Notes: $\mathrm{Ss}=\mathrm{S}$. sumatrana; $\mathrm{Gs}=\mathrm{G}$. sepium; $\mathrm{Pi}=P$. indicus; $\mathrm{Y}=$ wood density; $\mathrm{X}_{1}=$ fiber diameter; $X_{2}=$ fiber wall thickness; $X_{3}=$ lumen diameter; $X_{4}=$ vessel diameter; $X_{5}=$ ray height; $\mathrm{X}_{6}=$ ray width

The relative contribution and the relative contribution of determinant for all anatomical character factors to the total variation in wood density values show differences in the three tree species of Fabaceae (Table 4). The relative contribution for all anatomical character factors in S. sumatrana explained $99.8 \%$ of the total variation in wood density value. Fiber length, fiber diameter, fiber wall thickness, lumen diameter, vessel diameter, height ray and ray width had the relative contribution of determinant of $0.89 \%, 0.65 \%$, $0.58 \%, 0.81 \%, 0.93 \%, 0.96 \%$ and $0.95 \%$ respectively of the total wood density variance. In G. sepium, relative contribution for all anatomical character factors explained $97.4 \%$ of the total variation in wood density value. Fiber length, fiber diameter, fiber wall thickness, 
lumen diameter, vessel diameter, height ray and ray width had the relative contribution of determinant of $0.51 \%, 0.56 \%, 0.78 \%, 0.84 \%, 0.26 \%, 0.50 \%$ and $0.83 \%$ respectively of the total wood density variance. In $P$. indicus, relative contribution for all anatomical character factors explained $99.2 \%$ of the total variation in wood density. Fiber length, fiber diameter, fiber wall thickness, lumen diameter, vessel diameter, height ray and ray width had the relative contribution of determinant of $0.60 \%, 0.89 \%, 0.75 \%, 0.76 \%, 0.01 \%$, $0.55 \%$ and $0.74 \%$ respectively of the total wood density variance.

TABLE 4: The relative contribution of all anatomical characters for predicting wood density value of selected Fabaceae trees using multiple linier regression analysis.

\begin{tabular}{|c|c|c|c|c|c|c|c|c|c|}
\hline Species & $\begin{array}{l}\text { Anatomical } \\
\text { characters }\end{array}$ & $\mathbf{R}$ & $r^{2}$ & $\begin{array}{l}\text { Adjusted } r \\
\text { Square }\end{array}$ & $\begin{array}{l}\text { Std. } \\
\text { Error of } \\
\text { the } \\
\text { Estimate }\end{array}$ & $\mathbf{R}$ & $\mathbf{R}^{2}$ & $\begin{array}{l}\text { Adjusted } \\
\text { R Square }\end{array}$ & $\begin{array}{l}\text { Std. } \\
\text { Error of } \\
\text { the } \\
\text { Estimate }\end{array}$ \\
\hline \multirow{7}{*}{$\begin{array}{l}\text { S. } \\
\text { sumatrana }\end{array}$} & $\mathrm{FL}$ & +0.942 & 0.887 & 0.876 & 0.03008 & 0.999 & $99.8 \%$ & $99.5 \%$ & 0.00580 \\
\hline & FD & -0.808 & 0.653 & 0.618 & 0.05279 & & & & \\
\hline & FWT & +0.764 & 0.584 & 0.542 & 0.05790 & & & & \\
\hline & LD & -0.901 & 0.811 & 0.793 & 0.03891 & & & & \\
\hline & VD & -0.962 & 0.926 & 0.919 & 0.02435 & & & & \\
\hline & $\mathrm{RH}$ & -0.982 & 0.964 & 0.960 & 0.01706 & & & & \\
\hline & RW & +0.973 & 0.946 & 0.941 & 0.02073 & & & & \\
\hline \multirow[t]{7}{*}{ G. sepium } & $\mathrm{FL}$ & +0.711 & 0.505 & 0.456 & 0.02949 & 0.987 & $97.4 \%$ & $94.2 \%$ & 0.00961 \\
\hline & FD & -0.750 & 0.563 & 0.519 & 0.02772 & & & & \\
\hline & FWT & +0.882 & 0.778 & 0.755 & 0.01977 & & & & \\
\hline & LD & -0.918 & 0.843 & 0.828 & 0.01658 & & & & \\
\hline & VD & -0.512 & 0.262 & 0.189 & 0.03600 & & & & \\
\hline & $\mathrm{RH}$ & +0.710 & 0.504 & 0.455 & 0.02950 & & & & \\
\hline & RW & +0.912 & 0.832 & 0.815 & 0.01720 & & & & \\
\hline \multirow[t]{7}{*}{$P$. indicus } & $\mathrm{FL}$ & -0.777 & 0.603 & 0.570 & 0.05104 & 0.996 & $99.2 \%$ & $98.5 \%$ & 0.00961 \\
\hline & FD & +0.945 & 0.892 & 0.883 & 0.02658 & & & & \\
\hline & FWT & +0.864 & 0.747 & 0.725 & 0.04058 & & & & \\
\hline & LD & +0.873 & 0.762 & 0.742 & 0.03951 & & & & \\
\hline & VD & 0.078 & 0.006 & -0.077 & 0.08037 & & & & \\
\hline & $\mathrm{RH}$ & +0.743 & 0.552 & 0.514 & 0.05398 & & & & \\
\hline & RW & +0.861 & 0.741 & 0.720 & 0.04121 & & & & \\
\hline
\end{tabular}

The relative contribution of determinant for wood density value in S. sumatrana was determined by fiber, vessel and rays components, but but $G$. sepium was determined by fiber and rays components, and $P$. indicus was determined by fiber only. The high density wood is associated with thick fiber walls and large xylem vessels [41]. Fiber traits 
appear to be mayor determinants of wood specific gravity [42]. Wood density variation, mainly driven by fiber wall and lumen fraction $[43,44]$.

Vessel diameter, height and ray width factors tend to contribute negatively to wood density value of Fabacea tree species. Eucalyptus nitents wood with lower density tended to have higher vessel area, and lower fiber cell wall area, ring width, and latewood width [45].

\section{Conclusions}

Category of wood density of S. sumatrana, G. sepium and $P$. indicus are known variations based on altitude ranges. The relationship between wood density and altitude shows negative correlation on S. sumatrana, positive correlation on $G$. sepium and $P$. indicus. The length, diameter and lumen diameter of the fiber, the height and width of the pith radius increase with increasing altitude, while the vesel diameter decreases with increasing height. Diameter, wall thickness and fiber lumen diameter, and vesel diameter contribute significantly to the increase in wood density value.

\section{Acknowledgments}

The study was funded by a research grant from the Directorate General of Higher Education through the Research Center of Andalas University. Therefore, we would like to thank the Director of Directorate General of Higher Education and head of the Research Center of Andalas University.

\section{References}

[1] Rhee, S., Kitchener, D., Brown, T., Merrill, R., Dilts, R., and Tighe, S. (2004). Report on Biodiversity and Tropical Forest in Indonesia. Submitted in accordance with Foreign Assistance Act Section 118/119.February 20, 2004. USAID, Indonesia. pp.316. pdf. usaid.gov/pdf.docs/Pnada949.pdf

[2] Uryu, Y. et al. (2010). Sumatra's Forest, their Wildlife and the Climate. Windows in times: 1985, 1990, 2000 and 2009. WWFIndonesia, Jakarta. pp.74. http://awsassets.wwf.or.id/downloads/ wwf_indonesia_2010_sumatran_forests_wildlife_climat_report_for_dkn_bappenas. pdf. 
[3] Margono, B. A. et al. (2012). Mapping and monitoring deforestation and forest degradation in Sumatra (Indonesia) using Landsat times series data sets from 1990 to 2010. Environ. Res. Letters, 7, 1-10.

[4] Obidzinski, K. and Darmawan, A. (2010). Smallholder timber plantation development in Indonesia: what is preventing progress? Int. For. Review. 12(4), 339-348.

[5] Syofyan, L. et al. (2017). Wood anatomy of Fabaceae tree species in tropical rainforest, West Sumatra, Indonesia. Asian J. Sci. Technol. 8(11), 6405-6411.

[6] Sosef, M. S. M., Hong, L. T. and Prawirohatmodjo, S. (1998). Timber trees: lesser known timbers. In: Plant Resources of South-East Asia No. 5(3). Leiden, Netherlands. Backhuys Publishers.

[7] Oluwafemi, O. A. and Adegbenga, S.O. (2007). Preliminary report and utilization potential of Gliricidia sepium (Jacq.) Stud. for timber. Res. J. For. 1(2), 80-85.

[8] Edwin, P. and Ozarska, B. (2015). Bending properties of hardwood timbers from secundary forest in Papua New Guinea. J. Trop. Fort Sc. 27(4), 456-461.

[9] Xi, C. et al. (2016). Introduction, growth performances and ecological adaptabilities of Hongmu tree species (Pterocarpus spp.) in China. J. Trop. For. Sci. 28(3), 260-267.

[10] Zeidler, A. (2012). Variation of wood density in Turkish hazel (Corylus colurna L.) grown in Czech Republic. J. For. Sci. 58(4), 145-151.

[11] Miranda, I. and Pereira, H. (2015). Variation of wood and bark density and production in coppiced Eucalyptus globulus trees in a second rotation. iForest, 9, 270-275.

[12] Koman, S. and Feher, S. (2015). Basic density of hardwood depending on age and site. Wood Res. 60(6), 907-912.

[13] Fernandes, C. et al. (2917). Physical, chemical and mechanical properties of Pinus sylvestris wood at five sites in Portugal. iForest, 10, 669-679.

[14] Střelcová, K., Škvarenina, J., and Blaženec, M. (2007). Basic density of wood in different forest type. In: Bioclimatology and Natural Hazard, International Scientific Conference, Polána nad Detvou, Slovakia, September 17-20, 2007. cbks.cz/SbornikPolana07/pdf/Premyslovska_et_al.pd

[15] Nock, C. A. et al. (2009). Wood density and its radial variation in six canopy tree species differing in shade-tolerance in western Thailand. Annals Bot. 104, 297-306.

[16] Naji, H. R. et al. (2011). The effect of growth rate on wood density and anatomical characteristics of Rubber wood (Havea brasiliensis Muell. Arg.). Scholars Res. Library, 1(2), 71-80. 
[17] Sungpalee, W. et al. (2009). Intra- and interpseciffic variation in wood density and fine-scale spatial distribution of stand-level wood density in a northern Thai tropical montane forest. J. Trop. Ecol. 25, 359-370.

[18] Kiaei, M. (2012). Effect of site and elevation on wood density and shrinkage and their relationship in Carpinus betulus. For. Stud. China. 14(3), 229-234.

[19] Hernández-Calderón, E. et al. (2014). Altitudinal changes in tree leaf and stem functional diversity in a semi-tropical mountain. J. Veg. Sc. 25(4), 955-966.

[20] Pompa-García, M. and Venegas-González, A. (2016). Temporal variation of wood density and carbon in two elevational sites of Pinus cooperi in relation to climate response in Northern Mexico. PLoS ONE, 16(6): (https://doi.org/10.1371/journal.pone. 0156782)

[21] Woodall, C. W. et al. (2015). Forest production dynamics a long wood density spectrum in eastern US forest. Tree, 29, 299-310.

[22] Siliprandi, N. C. et al. (2016). Inter-site variation in allometry and wood density of Goupia glabra Aubl. In Amazonia. Braz. J. Biol., 76(1), 268-276.

[23] Cown, D.J. and Hutchison, J.D. (1983). Wood density as an indicator of the bending properties of Pinus radiata poles. NZ J. For. Sci. 13(1), 87-99.

[24] Kord, B., Kialashaki, A., and Kord, B. (2010). The within-tree variation in the wood density and shrinkage, their relationship in Populus euramericana. Turk. J. Agric. For. 34, 1211-126.

[25] Missanjo, E. and Matsumura, J. (2016). Wood density and mechanical properties of Pinus kesiya Royle ex Gordon in Malawi. Forest, 7(135), 1-10.

[26] Kaygin, B., Esnaf, S., and Aydemir, D. (2016). The effect of altitude difference on physical and mechanical properties of Scots Pine wood grown in Turkey - Sinop Province. Drvna Industrija. 67(4), 393-397.

[27] Guyette, R. P. and Stambaugh, M. (2003). The age and density of ancient and modern oak wood in streams and sediments. IOWA J. 24(4), 345-353.

[28] Chave, J. et al. (2006). Regional and phylogenetic variation of wood density across 2456 neotropical tree species. Ecol. Appl. 16, 2356-2367.

[29] Wong, T. M. (2002). A Dictionary of Malaysian Timbers. Revised by Lim, S. C. \& Chung, R. C. K. Malayan Forest Record; No. 30. Forest Research Institute Malaysia. Printed in Malaysia by Percetakan Haji Jantan, Kuala Lumpur, Malaysia. pp.201.

[30] Sass, E. J. (1958). Botanical Microtechnique, Third Edition.The lowa State University Press Amess, lowa. 
[31] Schmid, R. (2009). Sonication and other improvements on Jeffrey's Technique for macerating wood. J. Stain Technol. 57(5), 293-299.

[32] Rossi, S. et al. (2015). Growth and basic wood properties of black spruce along an alti-latitudinal gradient in Quebec, Canada. Annals For. Sci. 72, 77-87.

[33] Topaloğlu, E. et al. (2016). Effect of altitude and aspect on various wood properties of Oriental beech (Fagus orientalis Lipsky) wood. Turkish J. Agric. For. 40, 397-406.

[34] Liang, D. and Xin-Ying, Z. (1989). The ecological wood anatomy of the Lilac ((Syringa oblate var. giradiiRehd.) in Taibai Mountain. Acta Botanica Sinica. 31(2), 95-102.

[35] Roque, R. M., and Fo, M. T. (2007). Wood density and fiber dimensions of Gmelina arborea in fast growth trees in Costa Rica: relation to growth rate. Sistemas $y$ Recursos Forestales, 16(3), 267-2276.

[36] Meena, V. S. and Gupta, S. (2014). Wood anatomy of Albizia procera correlation between tropical and subtropical from different geographic zones of Indian subcontinent. Int. J. Sci. Tech. Res. 3(5), 1-18.

[37] Jiménez-Noriega, P. M. S. et al. (2017). Anatomical variation of five plant species along an elevation gradient in Mexico City basin within the Trans-Mexican Volcanic Belt, Mexico. J. MT. Sci. 14(11), 22182-2199.

[38] Zoghi, Z., Azadfar, D., and Khazaeian, A. (2013). Study of altitude and selection on fiber biometry properties of Fagus orientalis Lipsky. Nusantara Biosci. 5(1), 30-34.

[39] Yilmaz, M. et al. (2008). Relationships between environmental variable and wood anatomy of Quercus pontica C. Koch (Fagaceae). Fresenius Environ. Bul. 17(7b), 902-910.

[40] Zanne, A. E. et al. (2010). Angiosperm wood structure: Global pattern in vessel anatomy and their relation to wood density and potential conductivity. Amer. J. Bot. 97(2), 207-215.

[41] Santini, N. S., Schmitz, N., and Lovelock, C. E. (2012). Variation in wood density and anatomy in a widespread mangrove species. Trees, 26(5), 1555-1563.

[42] Fortunel, C. et al. (2013). Wood specific gravity and anatomy of branches and roots in 113 Amazonian rainforest tree species across environmental gradients. New Phytologist. (doi: 10.1111/nph.12632)

[43] Ziemińska, K. et al. (2013). Fiber wall and lumen fraction drive wood density variation across 24 Australian Anngiosperms. Aob Plants, 5, plt046; doi:10.1093/aobpla/plt046

[44] Ziemińska, K., Westoby, M., and Wright, I.J. (2015). Broad anatomical variation within a narrow wood density range - A study of twig wood across 69 Australian Angiosperm. PLoS ONE, 10(4): e0124892.doi:10.1371/journal.pone.0124892 
[45] Salvo, L. et al. (2017). Radial variation of density and anatomical features of Eucalytus nitens tree.Wood and Fiber Sci. 49(3), 1-11. 